\title{
Relationship of Brazing Microstructure and Ti-Cu-Ni Phase Diagram
}

\author{
Ming-Chi Ho ${ }^{1}$, Pei Jen Lo ${ }^{1}$, Wei-Liang Liu ${ }^{2}$ and Ker-Chang Hsieh ${ }^{1}$ \\ 1. Department of Materials and Optoelectronic Science, National Sun Yat-Sen University, Kaohsiung 804, Taiwan \\ 2. Metal Industries Research \& Development Center, Kaohsiung 804, Taiwan
}

\begin{abstract}
The brazing microstructures varied from gap size, brazing time and filler metal flow path. There are four types of microstructure found in using the powder form Ti15Cu15Ni filler metal. The microstructure was examined by optical metallography, SEM, X-ray and EPMA. Ti-Cu-Ni phase diagram was assessed and two isopleths were estimated to interpret the microstructure morphology and phases formed. The formation of brazing microstructure can be well described from the principles of phase diagram, solidification path and phase transformation.
\end{abstract}

Key words: Ti brazing, Ti-Cu-Ni, phase diagram.

\section{Introduction}

Titanium and its alloys have been widely used in the aerospace industry since they have high specific strength and high corrosion resistance. The brazing of titanium has been studied extensively with different filler metals [1-11]. According to the literature, the Ti-15Cu-15Ni filler metal has been used for the brazing of Ti-6Al-4V titanium alloy to make the aircraft jet engine components such as afterburner flame holder [6] and engine impeller [4] due to their good flowability, high temperature stability and corrosion resistance. The purpose of this study is to investigate the relationship between the brazing microstructure and the Ti-Cu-Ni phase diagram. And the same strategy could be applied to the solid state diffusion bonding $[12,13]$ or liquid phase diffusion bonding [14].

For the Ti-Cu-Ni ternary phase diagram, Takeuchi et al. [15] reported a $\mathrm{Ti}_{2} \mathrm{Ni}^{-} \mathrm{Ti}_{2} \mathrm{Cu}$ pseudo-binary eutectic reaction at $910{ }^{\circ} \mathrm{C}$ and the eutectic composition was around $11-17 \mathrm{wt}-\% \mathrm{Cu}, 22-26 \mathrm{wt}-\%$ $\mathrm{Ni}$ and 59-64 wt-\% Ti. Budberg and Alisova [16] did

Corresponding author: Ker-Chang Hsieh, Ph.D., professor, research fields: alloy, phase diagram. a detailed study in the $\mathrm{Ti}-\mathrm{Ti}_{2} \mathrm{Ni}_{-}-\mathrm{Ti}_{2} \mathrm{Cu}$ region. They reported a ternary eutectic at $900{ }^{\circ} \mathrm{C}$ with composition around $10 \mathrm{wt}-\% \mathrm{Cu}, 20 \mathrm{wt}-\% \mathrm{Ni}$ and balance Ti and the $\mathrm{Ti}_{2} \mathrm{Ni}_{-}-\mathrm{Ti}_{2} \mathrm{Cu}$ pseudo-binary eutectic temperature at $930{ }^{\circ} \mathrm{C}$. Pfeifer, Bhan and Schubert [17] reported an $800{ }^{\circ} \mathrm{C}$ isothermal diagram which showed that there was more than 10 at.- $\% \mathrm{Ni}$ solubility in the $\mathrm{Ti}_{2} \mathrm{Cu}$ phase. And the phase relationships in the Ti- $\mathrm{Ti}_{2} \mathrm{Ni}-\mathrm{Ti}_{2} \mathrm{Cu}$ region are in agreement with Budberg and Alisova's study. Recently, Jena et al. [18] reported an assessment ternary phase diagram. Based on the above literature studies, there are two intermetallic phases, $\mathrm{Ti}_{2} \mathrm{Ni}$ and $\mathrm{Ti}_{2} \mathrm{Cu}$, with certain amount of copper and nickel solubility will exist in the brazing microstructures. In the following text, the symbol will be the $\mathrm{Ti}_{2} \mathrm{Ni}$ phase with copper solubility and the symbol is the $\mathrm{Ti}_{2} \mathrm{Cu}$ phase with nickel solubility.

\section{Materials}

The commercial Ti-6Al-4V titanium plate with $1 / 8$ inch thickness was used as a base metal. The filler metal is a mixing alloy with composition at $15 \mathrm{wt}-\%$ $\mathrm{Cu}, 15 \mathrm{wt}-\% \mathrm{Ni}$ and $70 \mathrm{wt}-\% \mathrm{Ti}$. The mixed powder alloy was examined by DTA. There is an exothermic 
peak at $895{ }^{\circ} \mathrm{C}$ during heating which is due to the alloynization and intermetallic compound formation. After holding at $1,000{ }^{\circ} \mathrm{C}$ for 30 minutes to reach equilibrium, the cooling curve shows the liquidus at $960{ }^{\circ} \mathrm{C}$ and solidus at $925^{\circ} \mathrm{C}$. The flowability study has been performed under different gaps, joint length (14-42 $\mathrm{mm})$ and brazing time $(1,2,5$ minutes at $970{ }^{\circ} \mathrm{C}$ ). The results show that $\mathrm{Ti}-15 \mathrm{Cu}-15 \mathrm{Ni}$ has good flowability with Ti-6Al-4V at $970{ }^{\circ} \mathrm{C}$ brazing temperature except the gap larger than $0.54 \mathrm{~mm}$. There are pores found in the brazing joint under larger gap condition by using $\mathrm{X}$-ray photography.

\section{Brazing Experiment}

The specimen configuration for brazing study is shown in Fig. 1. Surface preparation of the titanium specimens was carried out within 12 hours of brazing. The material was degreased in acetone, dried and etched in a solution of $30 \%$ nitric acid and 3\% hydrofluoric acid balanced with water, rinsed in distilled water, dried.

For fixturing, the $0.05 \mathrm{~mm}$ thickness titanium foil was used to control the gap size. Specimen was carried out by clamping them in a vice and tack welding (GTA) from both sides. The metal powder alloy was mixed with binder to become paste form and carefully positioned along one fillet of the specimen prior to placing it in the furnace. Fig. 2 shows the specimen position in the reaction tube, the set-up of brazing furnace and the vacuum system.

Brazing on all specimens was done in a reaction tube that was evacuated to approximately $10^{-5}$ torr. Three brazing time periods (1, 2, 5 minutes) and three gap sizes $(0.05,0.10,0.15 \mathrm{~mm})$, total nine brazing conditions were performed to investigate the difference of brazing microstructures. The brazing procedure is holding at $970{ }^{\circ} \mathrm{C}$ for 1,2 , or 5 minutes and then pulling the reaction tube out for cooling. This brazing temperature was selected after preliminary DTA and flowability studies of the powder filler metal.
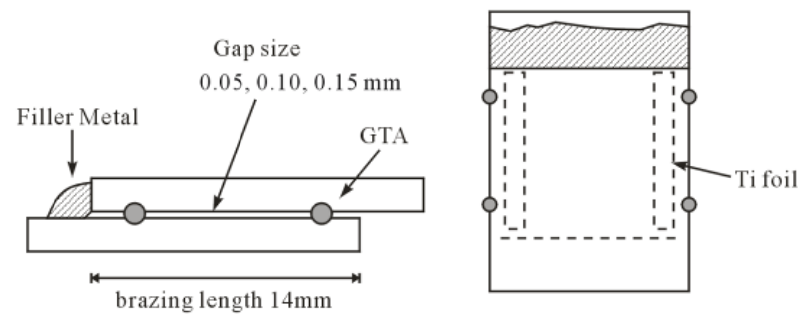

Fig. 1 The specimen configuration.

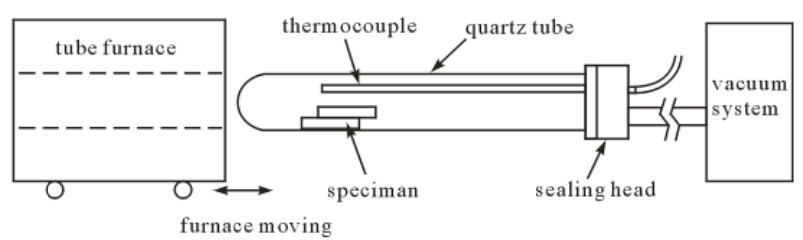

Fig. 2 The experimental set-up.

\section{Examination of Brazed Joints}

All as-brazed specimens were examined metallographically on the cross section along the liquid metal flow direction. The etching solution formula was $100 \mathrm{~mL} \mathrm{H}_{2} \mathrm{O}+4 \mathrm{~mL} \mathrm{HCl}+3 \mathrm{gm}$ $\mathrm{NH}_{4} \mathrm{HF}_{2}$. Several selected specimens were examined under SEM and EPMA for detail microstructure and composition analysis.

\section{Results and Discussion}

The brazing microstructures varied from gap size, brazing time and filler metal flow path. These different microstructures were classified as A, B, C and D types. The formation of these microstructures can be interpreted according to the assessed $\mathrm{Ti}-\mathrm{Cu}-\mathrm{Ni}$ phase diagram and two isopleths were estimated as the sections shown in Fig. 3. The isopleth through Ti and Ti15Cu15Ni is shown in Fig. 4. There is a type II four-phase equilibrium, $\mathrm{L}+\beta-\mathrm{Ti}=\varepsilon+\eta$, at $930{ }^{\circ} \mathrm{C}$ and the $\mathrm{L}+\varepsilon+\eta$ three-phase equilibrium ends at the $\mathrm{Ti}_{2} \mathrm{Ni}-\mathrm{Ti}_{2} \mathrm{Cu}$ pseudo-binary eutectic at $910{ }^{\circ} \mathrm{C}$ [15]. According to Budberg and Alisova's study [16], the phase reaction in this region is type $\mathrm{I}$ as, $\mathrm{L}=\beta$-Ti $+\varepsilon+\eta$, at $900{ }^{\circ} \mathrm{C}$. Since titanium is a reactive metal, their DTA results could be affected by the reaction with container or contaminate with oxygen or nitrogen etc., impurities. A careful DTA study is necessary to verify this phase reaction. In this study our metallography 


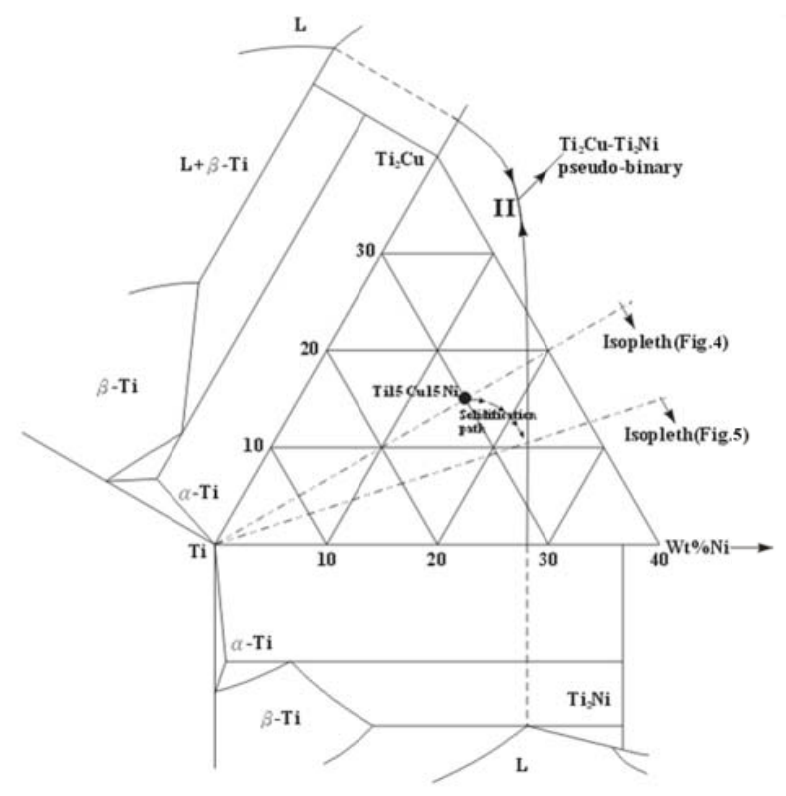

Fig. 3 Two isopleth sections and the solidification path of the Ti15Cu15Ni brazing filler metal.

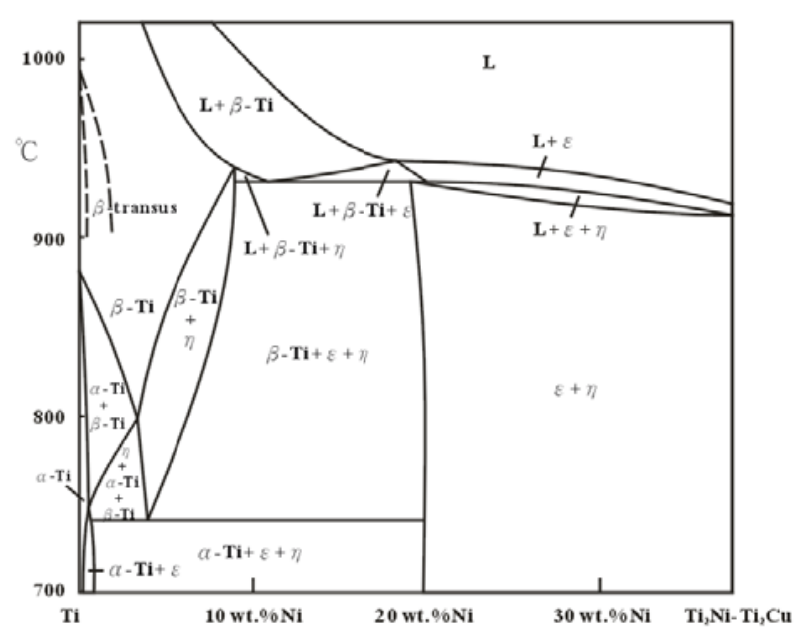

Fig. 4 The isopleth of Ti-Ti15Cu15Ni section.

results were consistent with Takeuchi's. Another four-phase reaction is type I eutectoid reaction as $\beta$-Ti $=\alpha-\mathrm{Ti}+\varepsilon+\eta$ at $738{ }^{\circ} \mathrm{C}[15]$. The phase boundaries of two-phase and three-phase regions are estimated by this study. Fig. 5 is another isopleth with position near Ti-Ni binary according to Fig. 3 .

Type A microstructure is shown in Fig. 6a which includes five different zones in the brazing region. In order to interpret the formation of type A microstructure, the relationship between phase diagram and phase formation in the brazing process will be discussed. There is a continuous composition range between the base metal and residual filler liquid metal at the end of brazing temperature, $970{ }^{\circ} \mathrm{C}$, as shown in Fig. 6b. The composition range is divided to five composition regions $\mathrm{A} 1 \sim \mathrm{A} 5$ and the dash curve is the transus of Ti-6Al-4V alloy. Each composition region (A1 A5) will have a phase change following the isopleths in Fig. $6 \mathrm{~b}$ during the cooling stage. And each region corresponds to the microstructure zones in type A microstructure.

The details could be discussed as follows, (I) base metal zone (A1)-There is an un-react equiax $\alpha$-Ti grain and intergranular $\beta$-Ti phase., (II) diffusion zone (A2) $-\mathrm{Ni}$ and $\mathrm{Cu}$ diffuse into the $\alpha$-Ti phase which decrease $\beta$ transus temperature and transform to $\beta$-Ti phase at the brazing temperature. The needle type $\alpha$-Ti phase is formed due to the new formed $\beta$-Ti phase transforming back to $\alpha$-Ti phase during cooling, [4], (III) finer grain zone (A3) - The morphology in this region seems due to ternary eutectoid reaction $(\beta-\mathrm{Ti}=\alpha-\mathrm{Ti}+\varepsilon+\eta)$ as cooling from the brazing temperature. The (IV) growth zone (A4)-Since $\beta$-Ti phase cooling through the $\beta-\mathrm{Ti}+\eta$ two phase region, there are a few of coarse $\eta$ phase growing within the finer grain matrix, and (V) filler metal zone (A5) - The residual liquid filler metal solidified along the liquidus and formed eutectic morphology. This morphology varied along the filler metal flow path that was due to the overall composition of the

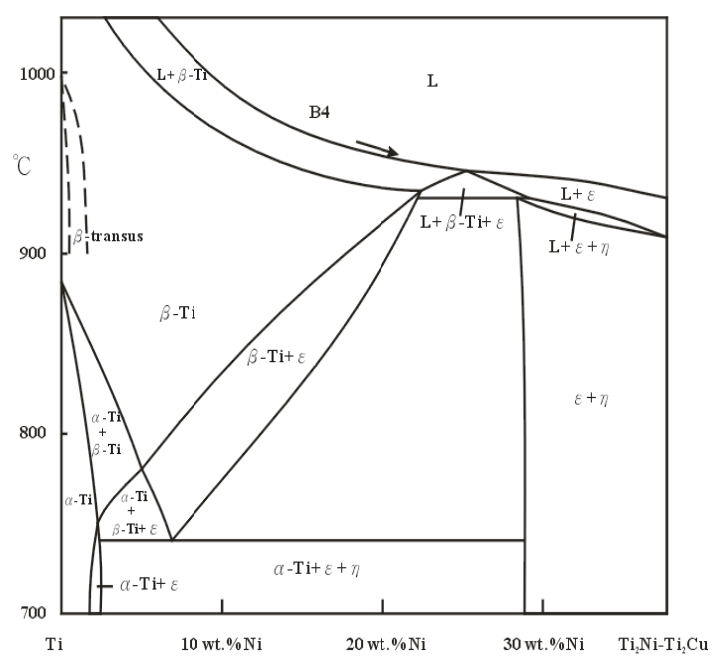

Fig. 5 The isopleth near the Ti-Ni binary. 


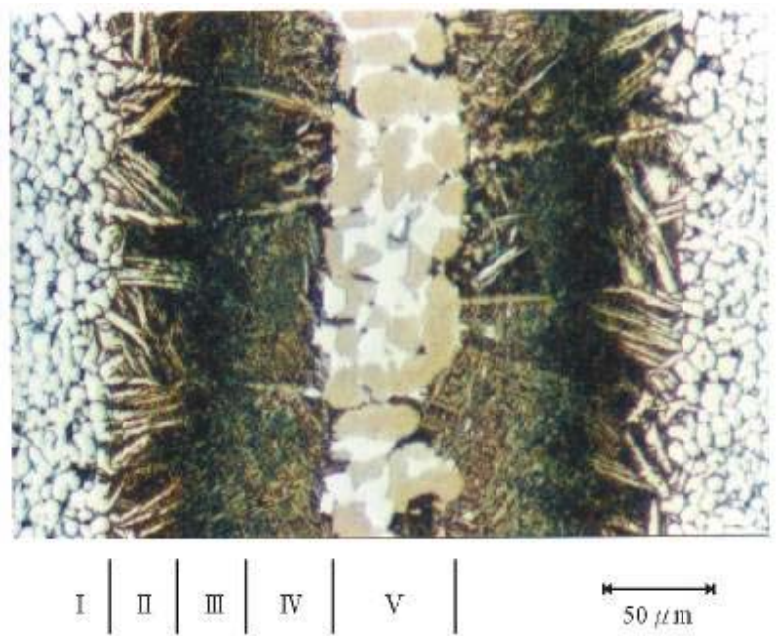

(a)

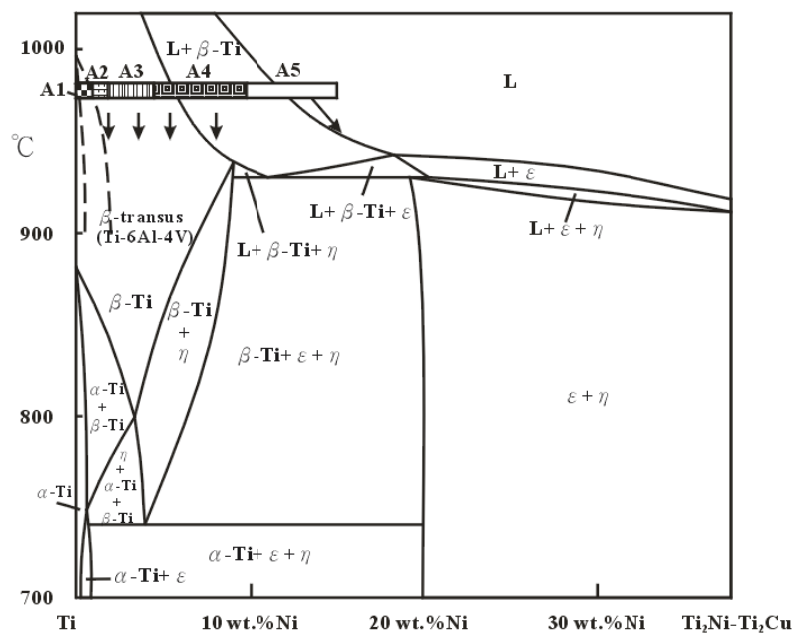

(b)

Fig. 6 (a) Type A microstructure: (I) base metal zone, (II) diffusion zone, (III) finer grain zone, (IV) growth zone, and (V) filler metal zone; (b) The isopleth of Ti-Ti15Cu15Ni section with A1-A5 composition region.

Table 1 The EPMA analysis results for the e \& $\mathrm{h}$ phases in zone $\mathrm{V}$ (brazing condition: $970{ }^{\circ} \mathrm{C}$ for 1 minute and $0.15 \mathrm{~mm}$ gap).

\begin{tabular}{lllllll}
\hline \multirow{2}{*}{ Position } & Comp. wt- $\%$ & \multicolumn{3}{c}{$\varepsilon$ phase } & \multicolumn{3}{c}{$\eta$ phase } \\
\cline { 2 - 7 } & $\mathrm{Ti}$ & $\mathrm{Ni}$ & $\mathrm{Cu}$ & $\mathrm{Ti}$ & $\mathrm{Ni}$ & $\mathrm{Cu}$ \\
\hline $\mathrm{a}$ (inlet) & 59.9 & 27.1 & 13.0 & 58.4 & 12.9 & 28.7 \\
$\mathrm{~b}$ & 60.6 & 26.7 & 12.7 & 59.7 & 13.9 & 26.4 \\
$\mathrm{c}$ & 62.2 & 30.6 & 7.1 & 61.6 & 14.3 & 24.0 \\
$\mathrm{~d}$ & 62.4 & 29.6 & 8.0 & 62.1 & 15.2 & 22.7 \\
$\mathrm{e}$ & 61.8 & 30.1 & 8.1 & 61.5 & 14.4 & 24.1 \\
$\mathrm{f}$ (tail) & 61.6 & 34.4 & 4.0 & $* 68.7$ & $* 26.8$ & $* 4.5$ \\
\hline
\end{tabular}

* White needle phase.

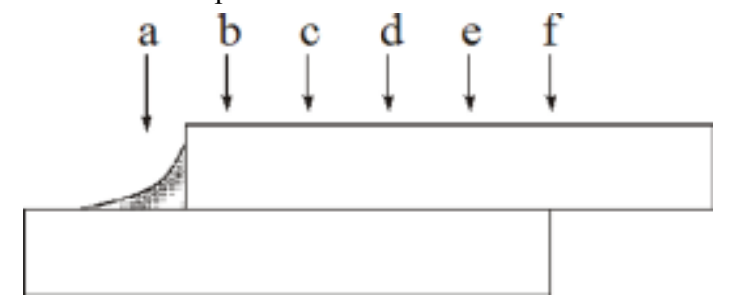

residual liquid filler metal changed also. In this region, the chemical compositions of each phase were examined by EPMA and the results are shown in Table 1. The composition of . phase (Ni-rich phase with white color) shows the copper content decreases along with the flow path of liquid filler metal and the nickel content is vis-à-vis. The composition of $\eta$ phase (Cu-rich phase with gray color) did not show large change.

The type B microstructure is shown in Fig. 7a which was divided into four different zone, (I) base metal zone, (II) diffusion zone, (III) finer grain zone with white needle phase, and (IV) filler metal zone which is mainly $\varepsilon$.phase. The formation of microstructure can be interpreted by Fig. 7b. This figure is same as Fig. 5 with a continuous composition range between base metal and the residual filler metal. The composition region $\mathrm{B} 1$ and $\mathrm{B} 2$ will form the base metal zone and diffusion zone, respectively. The white needle phase precipitated in zone III is due to the composition region cooling through $\beta$-Ti $+\varepsilon$. two phase region. And the residual liquid B4 solidified along the liquidus and formed $\varepsilon$.phase mostly. The compositions of zone (III) white needle phase and 


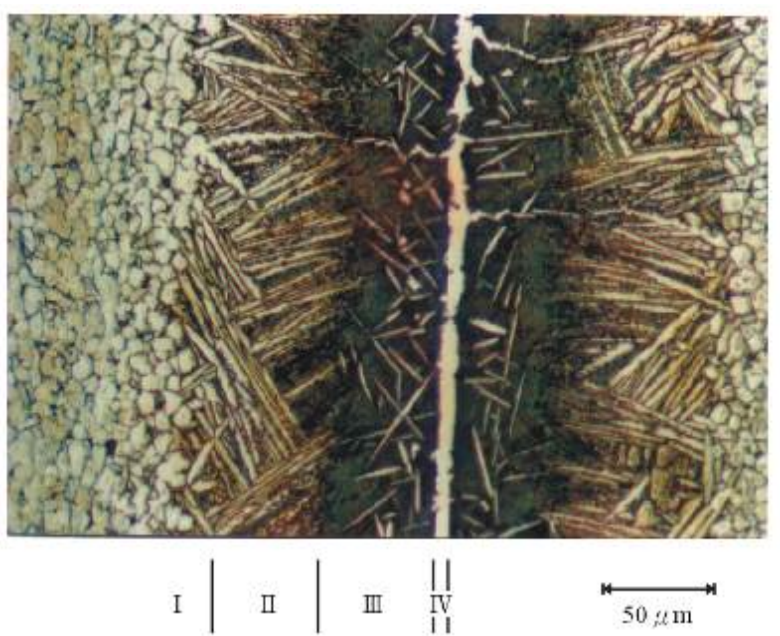

(a)

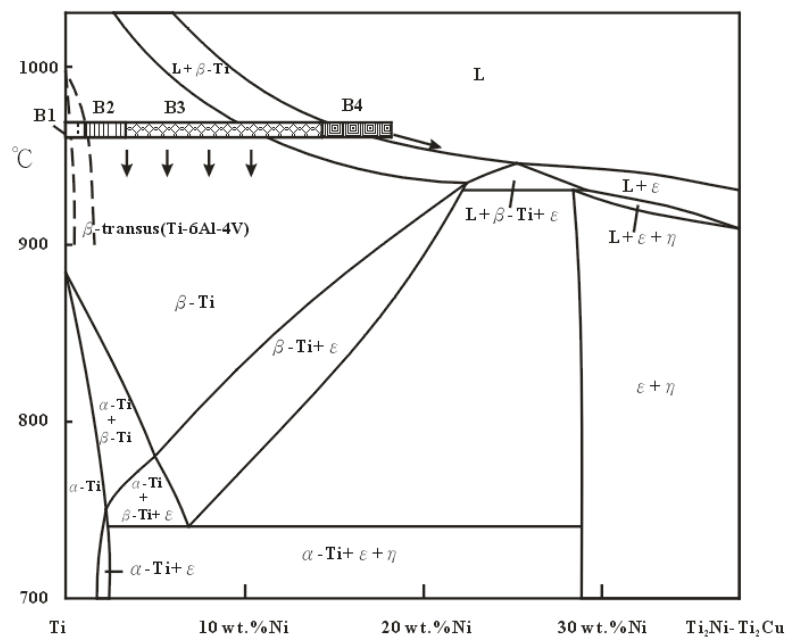

(b)

Fig. 7 (a) Type B microstructure: (I) base metal zone, (II) diffusion zone, (III) finer grain zone with white needle phase, and (IV) filler metal zone; (b) The isopleth near Ti-Ni binary with B1-B4 composition regions.

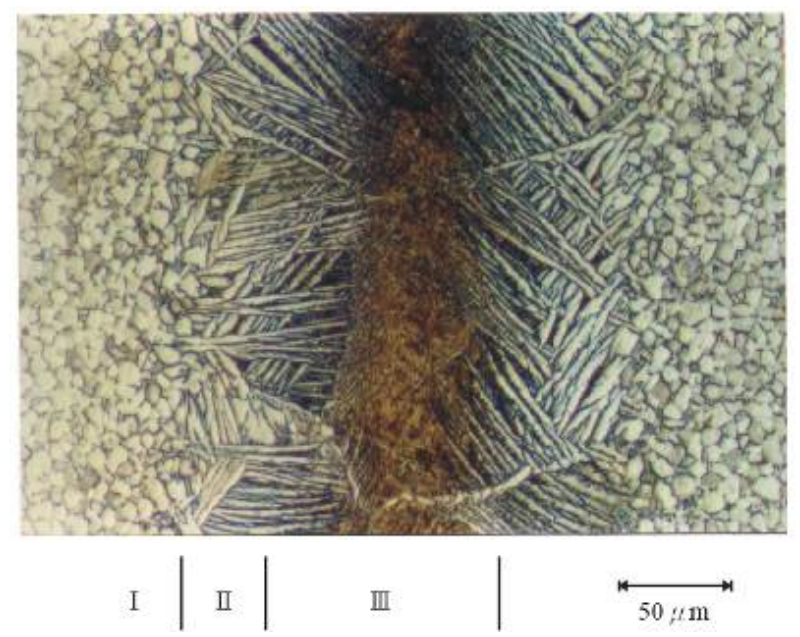

(a)

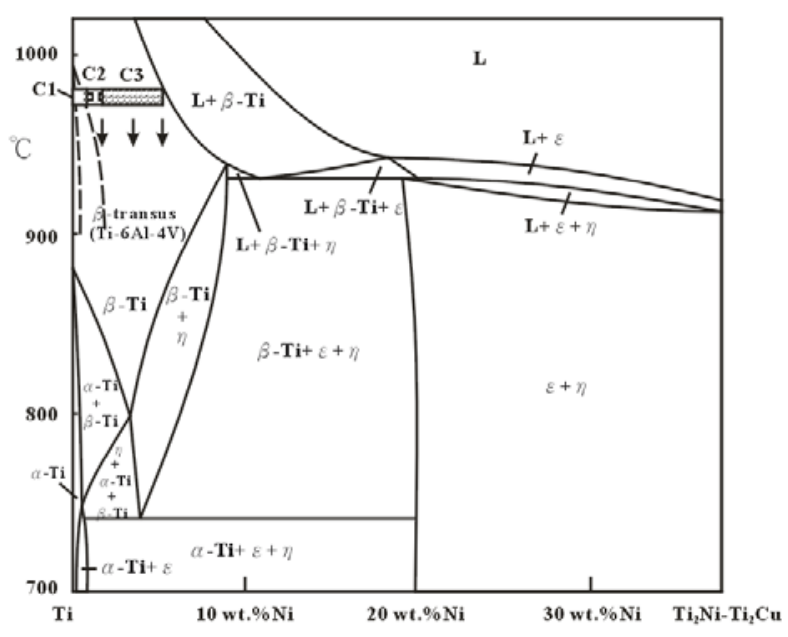

(b)

Fig. 8 (a) Type C microstructure: (I) base metal zone, (II) diffusion zone, and (III) finer grain zone; (b) The isopleth of Ti-Ti15Cu15Ni section with C1-C3 composition region.

zone (IV) $\varepsilon$ phase are listed at the last row of Table 1. The white needle phase has higher titanium content. During the flowing of liquid filler metal, the copper content consumed faster than the nickel and the composition of the residual filler liquid in the tail region may form the $\varepsilon$. phase only. The solidification path of the residual filler metal in this brazing process shifts to the Ti-Ni binary as shown in Fig. 3.

The type $\mathrm{C}$ microstructure is shown in Fig. 8a which includes (I) base metal zone, (II) diffusion zone, and (III) finer grain zone. The composition region $\mathrm{C} 1$, $\mathrm{C} 2$ and $\mathrm{C} 3$ in Fig. $8 \mathrm{~b}$ formed three zones of type $\mathrm{C}$ microstructure, respectively. The type D microstructure is shown in Fig. 9a which includes (I) base metal zone and (II) diffusion zone. And the composition region D1 and D2 in Fig. 9b formed the base metal zone and diffusion zone, respectively. These two types are found in the narrow gap specimen. There is no filler liquid left to form the filler metal zone as Type A and B microstructures. The microstructure type along with the liquid filler metal path for each brazing condition were examined and summarized in Table 2.

According to these results, type A and B are formed at large gap specimens and type $\mathrm{C}$ and $\mathrm{D}$ are formed 


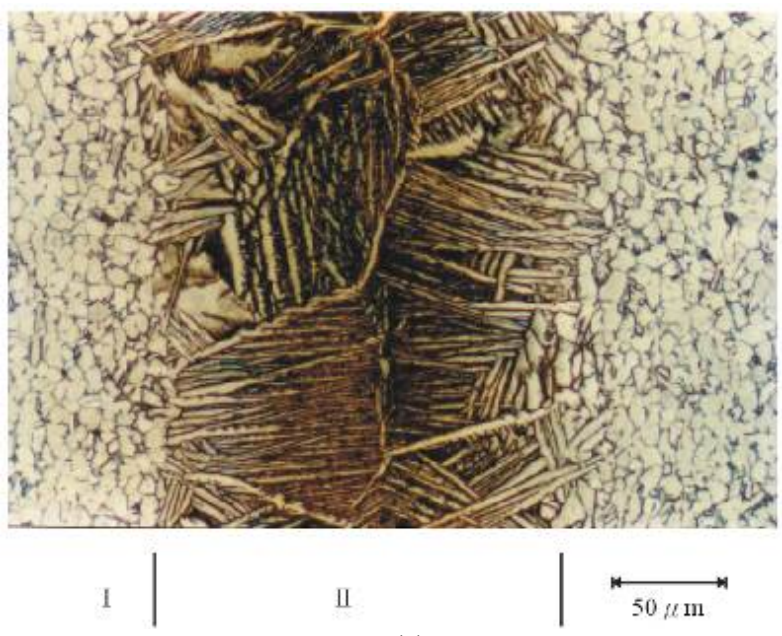

(a)

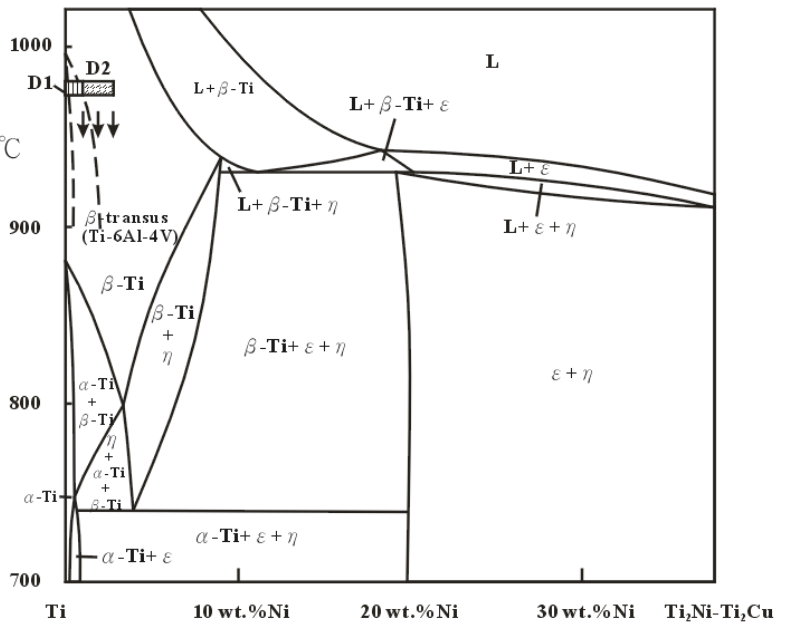

(b)

Fig. 9 (a) Type D microstructure: (I) base metal zone, and (II) diffusion zone; (b) The isopleth of Ti-Ti15Cu15Ni section with D1-D2 composition region shown.

Table 2 The microstructure type along with the liquid filler metal flow path for each brazing condition.

\begin{tabular}{llllllllll}
\hline & Gap size & \multicolumn{3}{c}{$0.05 \mathrm{~mm}$} & \multicolumn{3}{c}{$0.10 \mathrm{~mm}$} & \multicolumn{3}{c}{$0.15 \mathrm{~mm}$} \\
\cline { 2 - 9 } $970{ }^{\circ} \mathrm{C}$ brazing time & front & middle & tail & front & middle & tail & front & middle & tail \\
\hline $1 \mathrm{~min}$ & $\mathrm{C}$ & $\mathrm{D}$ & $\mathrm{D}$ & $\mathrm{C}$ & $\mathrm{C}$ & $\mathrm{C}$ & $\mathrm{A}$ & $\mathrm{A}$ & $\mathrm{B}$ \\
$2 \mathrm{~min}$ & $\mathrm{C}$ & $\mathrm{C} \sim \mathrm{D}$ & $\mathrm{D}$ & $\mathrm{A}$ & $\mathrm{A}$ & $\mathrm{B}$ & $\mathrm{A}$ & $\mathrm{A} \sim \mathrm{B}$ & $\mathrm{A} \sim \mathrm{B}$ \\
$5 \mathrm{~min}$ & $\mathrm{~A} \sim \mathrm{C}$ & $\mathrm{C}$ & $\mathrm{D}$ & $\mathrm{A}$ & $\mathrm{A} \sim \mathrm{B}$ & $\mathrm{B}$ & $\mathrm{A}$ & $\mathrm{A}$ & $\mathrm{A}$ \\
\hline
\end{tabular}

mainly at narrow gap specimens. In the narrow gap brazing condition, the nickel and copper content in the liquid filler metal quickly decreased due to interdiffusion. And the residual titanium rich liquid would solidify shortly which might block the liquid metal supply and cause pores in the brazing joints.

In order to identify the phases formed in the diffusion zone, finer grain zone and growth zone, three selected specimens were cut from the plane section to do the X-ray surface diffraction analysis. The $\varepsilon$. phase is the mainly new formed phase in the diffusion and fine grain zones. The X-ray patterns were interpreted according to the JCPDS cards [19].

\section{Conclusions}

The brazing microstructure can be successfully interpreted by the principles of the filler metal phase diagram, solidification path, diffusion and phase transformation. In the other way, the brazing microstructure can be predicted. This will provide the valuable information in the development of brazing process, such as, filler metal selection, brazing temperature and time or the possibility of brittle phase precipitation etc.

\section{Acknowledgments}

The authors are pleased to acknowledge the financial support for this research provided by National Science Council, Grant No. 96-2221-E-110-059-MY3.

\section{References}

[1] Kaarlela, W. T., and Margolis, W. S. 1974. "Development of the Ag-Al-Mn Brazing Filler Metal for Titanium.” Welding J. 53 (10): 629-36.

[2] Tucker, M. S., and Wilson, K. R. 1969. "Attack of Ti-6Al-4V by Silver Base Brazing Alloys." Welding J. 48: $521 \mathrm{~s}-7 \mathrm{~s}$.

[3] Howden, D. G., and Monroe, R. W. 1972. "Suitable Alloys for Brazing Titanium Heat Exchangers." Welding J. 51 (1): 31-6.

[4] Lan, S. W. 1982. "Laminated Brazing Filler Metals for Titanium Assemblies.” Welding J. 61 (10): 23-8.

[5] Onzawa, T., Suzumura, A., and Ko, M. W. 1990. "Brazing of Titanium Using Low-Melting-Point Ti-based 
Filler Metals." Welding J. 69 (12): 462s-7s.

[6] Hooven, W. T. 1982. "Selected Furnace Brazed Components for Aerospace Industry." Welding J. 61 (10): $15-20$.

[7] Elrod, S. D., Lovell, D. T., and Davis, R. A. 1973. "Aluminum Brazed Titanium Honeycomb Sandwich Structure-A New System." Welding J. 52 (10): 425s-32s.

[8] Takemoto, T., and Okamoto, I. 1988. "Intermetallic Compounds Formed during Brazing of Titanium with Aluminium Filler Metals." J. Mat. Sci. 23 (4): 1301-8.

[9] Schwartz, M. 1983. "Brazing of Reactive Metals and Refractory Metals." In Metals Handbook, 9th Ed., Vol. 6, 1049-54, Ohio: Metals Park.

[10] Liaw, D. W., Wu, Z. Y., Shiue, R. K., and Chang, C. S. 2007. "Infrared Vacuum Brazing of Ti-6Al-4V and $\mathrm{Nb}$ Using the Ti-15Cu-15Ni Foil." Mater. Sci. Eng. A 454-5, 104-13.

[11] Chang, C. T., Yeh, T. Y., Shiue, R. K., and Chang, C. S. 2011. "Microstructural Evolution of Infrared Brazed CP-Ti Using Ti-Cu-Ni Brazes." J. Mater. Sci. Technol. 27 (2): 131-8.
[12] Wells, R. R. 1976. "Microstructural Control of Thin-Film Diffusion-Brazed Titanium.” Welding J. 56 (1): 20s-7s.

[13] Freedman, A. H. 1971. "Basic Properties of Thin-Film Diffusion-Brazed Joints in Ti-6Al-4V.” Welding J. 50 (8): 343s-56s.

[14] Ramirez, J. E., and Liu, S. 1992. "Diffusion Brazing in the Nickel-Boron System." Welding J. 71 (10): 365s-75s.

[15] Takeuchi, Y., Watanabe, M., Yamabe, S., and Wada, T. 1968. "Eutektische Titan- und Zirkonium-Lote." Metall. 22: 8-15.

[16] Budberg, P. B., and Alisova, S. P. 1979. "Phase Constitution of the Ti-Ti ${ }_{2} \mathrm{Ni}_{-}-\mathrm{Ti}_{2} \mathrm{Cu}$ system." Dokl. Akad. Nauk SSSR 244 (6): 1370-3.

[17] Pfeifer, H. U., Bhan, S., and Schubert, K. 1968. "Constitution of the Ti-Ni-Cu System and Some Quasihomologous Alloys." J. Less-Common Metals 14: 291-302.

[18] Jena, A. K., Rajendraprasad, S. B., Gupta, K. P., and Sharma, R. C. 1987. "The Copper-Nickel-Titanium System.” J. Alloy Phase Diagrams 3 (2): 87-104.

[19] JCPD cards, Joint Committee on Powder Diffraction Standards. 